\title{
The Biological Activity of Aqueous and Methanolic Extracts of Juglans regia on Yeasts and Pathologic Bacteria
}

\author{
Furdos N Jafer and Lina A Naser*
}

Biology Department, Science College, Basrah University, Iraq

${ }^{*}$ Corresponding author: Lina A Naser, Biology Department, Science College, Basrah University, Iraq, Tel: 07705698101; E-mail: lina1977_abbas@yahoo.com

Received date: October 21, 2019; Accepted date: June 05, 2020; Published date: June 12, 2020

Citation: Jafer FN, Naser LA (2020) The Biological Activity of Aqueous and Methanolic Extracts of Juglans regia on Yeasts and Pathologic Bacteria. Arch Clin Microbiol Vol. 11 No. 3:113

Copyright: (c) 2020 Jafer FN, et al. This is an open-access article distributed under the terms of the Creative Commons Attribution License, which permits unrestricted use, distribution, and reproduction in any medium, provided the original author and source are credited.

\section{Abstract}

Background: The plant extract can be used as a natural alternative to control of pathogenic yeasts and bacteria in general and to reduce the risk of antibiotic-resistant pathogens.

Methods: Diffusion agar method was used to examine the antifungal and antibacterial activity of both aqueous and methanolic Juglans regia extracts. For yeasts, The MIC values were determined by the standard serial dilution assay using serial dilutions of the aqueous and methanolic extracts $(300,200,100,50,25) \mu \mathrm{g} / \mathrm{L})$. The MIC for bacteria was done using Muller-Hinton agar. The concentrations of the extracts tested were $(500,250,100,50) \mu \mathrm{g} / \mathrm{ml}$.

Results: Juglans regia extracts showed activities against Malassezia furfur yeast, Methanolic extract exhibits more activity than aqueous extract. The Minimum Inhibition Concentrated rate (MIC) for Malassezia furfur methanolic extract was $75 \mu \mathrm{g} / \mathrm{ml}$. The extracts also examined on Candida albicans opportunistic yeast in the mouth and found to be more active than $M$. furfur were MIC 50 $\mu \mathrm{g} / \mathrm{ml}$. The biological activity of aqueous and methanolic extracts were also examined against six pathogenic bacteria isolated from patients suffering from different diseases from several hospitals in Basrah, including Staphylococcus aureus, Escherichia coli, Salmonella typhi, Proteus mirabilis, pseudomonas aeruginosa and Vibrio parahaemolyticus. The Methanolic extract showed an effective effect in inhibiting all bacterial species compared with the aqueous extract.

Conclusion: This study provides the possibility of using a natural plant such as Juglans regia as antimicrobial agent for many pathogenic yeasts and bacteria.

\section{Keywords: Juglans regia; Activity; Antifungal;} Antibacterial

\section{Introduction}

Some fungi found on human skin and scalp, such as Malassezia, and are found in some human cavities such in the mouth and vagina such as Candida. Malassezia is yeast that is naturally found on the skin of healthy human and warmblooded animals and can become a pathogen and cause skin diseases such as Pityriasis versicolor [1-4].

This yeast tends to fat, therefore called lipophilic and all sexrelated species of the seven species considered to be lipophilic, except M. Pachyderms. Therefore, the medium used to isolate should contain fatty acids [5-7]. Olive oil is one of the most common fats used to isolate this yeast. The most important characteristic of this yeast is the possession of the enzyme Lipase [8]. Candida is bivalent yeast that is co-existent in warm-blooded animals, including humans. It colonizes the mucous surfaces of the mouth, vagina, and digestive tract. It can cause various infections, according to the host. The infection caused by Candida is called Candidiasis and was two types oral (Thrash) and vaginal candidiasis. Candida is dimorphic yeast it has two phases, yeast phase, and the filament phase and is transformed from one phase to another depending on $\mathrm{PH}$ and temperature and the presence of other compounds such as Acetylglucosamine [9-12].

Some primitive methods of decoration are used, such as the use of Juglans regia to whiten the teeth and apply dye to the lips [13].

The walnut trees live in northern Iran, the Caucasus, Baluchistan, and Armenia, and these perennial trees date back to 500 years [14]. It was used as an antifungal agent especially in the treatment of ringworm infections for the first time in 1950 by the world Dorlan. The extract successfully used in inhibiting yeast growth Candida albicans [15].

The plant extract can be used as a natural alternative to control of pathogenic bacteria in general and to reduce the risk of antibiotic-resistant pathogens in particular [16].

In a study carried out by Sharafati [17], the Juglans regia extract showed a wide spectrum effect against bacteria such 
as Staphylococcus aureus, Streptococcus mutans, Escherichia coli, Pseudomonas aeruginosa.

The discovery of antibiotics in the last century led to a decrease in disease rates and deaths due to infectious diseases, but the inappropriate use of these antibiotics resulted from the emergence of groups of resistant bacteria that threaten human health, especially with immunocompromised patients, creating the need to research new types of natural anti-microbial substances to control on different diseases and has led to an increase in interest in medicinal plants where $25-50 \%$ of the current pharmaceuticals derived from plants because chemically manufactured drugs have side effects, while there is no such effects in medical alternatives such as plant extracts [18].

Therefore, the aim of this study was to study the antimicrobial effect of Juglans regia extract (aqueous and Methanolic) on yeasts and pathogenic bacteria isolated from patients suffering from different diseases in Basrah hospitals.

\section{Materials and Methods}

Preparation of aqueous and methanolic Juglans regia extracts: $20 \mathrm{gm}$ of the powdered dry bark of Juglans regia were weight separately in different flasks, one of them percolated with $200 \mathrm{ml}$ of methanol this flask was proper sealed with aluminum foil and left with stirring magnetic stirrer for 24 hours at room temperature. The solution was then filtered using a funnel filled in a filter paper and the methanol extracts collected in Petri dishes and dried at room temperature. The above procedure was repeated with the use of $200 \mathrm{ml}$ of distilled water to prepare the aqueous extract [19].

\section{Isolation of yeasts}

Malassezia yeast isolated from person with pityriasis versicolor by used of skin scraping that cultured in Sabouraud Dextrose Agar (SDA) medium supplemented with $20 \mathrm{ml}$ of olive oil per liter, 0.01 cyclohexamide and 10 drops of tween 20. The isolated Malassezia classified as Malassezia furfur While Candida yeast isolated from person with mouth candidiasis infection.

Oral swab used and cultured in (SDA) both yeasts incubated in $32^{\circ} \mathrm{C}$ the isolated candida classified as Candida albicans by using of germ tube test.

\section{Study the effect of alternative oils on the Malassezia yeast growth}

Appropriate medium for the growth of Malassezia is the added to some oils communally olive oil and Tween 80 as mentioned in the introduction, but in this experiment has been replaced olive oil with some oils such as sunflower oil and castor oil and olive oil treatment compared to add to use a combination of the three types as an independent treatment, the previous oils were added by $20 \mathrm{ml}$ per liter of SDA media. Each of the cultivars was poured into the dishes. The yeast was then planted on the medium in a streaking manner, taking into consideration three replicates per treatment and incubated at $32^{\circ} \mathrm{C}$.

\section{Antifungal activity test}

Diffusion agar method was used to examine the antifungal activity of both aqueous and methanolic extracts toward Malassezia furfur and Candida albicans using (SDA) medium, $10 \mu \mathrm{l}$ of each yeast suspension add on the surface of the medium then spread with sterile L-shape glass rod, after drying, two $5 \mathrm{~mm}$ diameter pores was made in the center of plates , $100 \mu \mathrm{l}$ of both crud extracts was add separately in the pores of plates with used of control treatment for each yeast, cultures were incubated at $32^{\circ} \mathrm{C}$ for 2 days after incubation period the diameter of the inhibition zones were evaluated in millimeters [20].

\section{The minimum inhibitory concentration (MIC) test for yeast}

The MIC values were determined by the standard serial dilution assay using serial dilutions of the aqueous and methanolic extracts $(300,200,100,50,25), \mu \mathrm{g} / \mathrm{L})$. The suspensions of yeasts were prepared and standardized to a turbidity equivalent to that of 0.5 MacFerland scale $(1 \times 106$ $\mathrm{cfu} / \mathrm{ml}) .100 \mu \mathrm{l}$ of yeast suspension add on the surface of the media then media incubated in $32^{\circ} \mathrm{C}$, The MIC values in this assay were indicated by the absence of yeast growth at the minimal concentration of the extract.

\section{Antibacterial activity test}

The Muller Hinton agar was used for the purpose of measuring the biological efficacy of six types of pathogenic bacteria Staphylococcus aureus, Escherichia coli, Salmonella typhi, Proteus mirabilis, Pseudomonas aeruginosa and Vibrio parahaemolyticus were isolated from patients suffering from different diseases admitted to Al Fayhaa General Hospital and Al Shifa General Hospital in Basrah. The well-diffusion methods were used by Bansode and Chavan [21] $0.1 \mathrm{ml}$ of the bacteria was distributed in the Muller Hinton agar dish using a sterile swab and then holes were made in the center of the plates using a cork borer. $100 \mu \mathrm{l}$ of both aqueous and methanolic crude extracts were placed separately in each hole. One distilled water was placed in a single hole as a control. The dishes were then left for half an hour after being placed in the incubator for 24 hours at $37^{\circ} \mathrm{C}$. The effectiveness of the two extracts was determined by measuring the diameter of the inhibition zone formed around the hole $\mathrm{mm}$.

\section{The Minimum Inhibitory Concentration (MIC) test for bacteria}

The MIC of different concentrations of Methanolic and aqueous Juglans regia extracts against tested bacterial isolates were done using Muller-Hinton agar. The concentrations of the extracts tested were $(500,250,100,50) \mu \mathrm{g} / \mathrm{ml}$, the assays were performed three times for each bacterium. Plates were 
inoculated with $0.1 \mathrm{ml}$ of the bacterial suspension was distributed in the Muller Hinton agar dish using a sterile swab and then holes were made using a cork borer. Different extract was placed in each hole. The plates then left for half an hour after being placed in the incubator for 24 hours at $37^{\circ} \mathrm{C}$. The highest dilution of extract that showed no visible bacterial growth per hole was considered as MIC Standards.

\section{Results}

\section{Preparation of aqueous and methanolic Juglans regia extracts}

After the preparation of the extract it was observed that the aqueous extract is characterized by viscous nature while the methanolic extract appeared in the crystalline nature due to the difference in the type of chemical compounds extracted from each one.

\section{Isolation and Diagnosis of Yeast}

After the Malassezia Yeast isolate from the Skin infection pityriasis versicolor the colony was raised and smooth initially and get dry and wrinkle in time the color of colony was creamy to a slightly yellowish-colored. The microscopic examination indicated that it represented the $M$. Furfur.

Species $M$. furfur is an ellipsoids yeast with small collarets and contains a bud or scar from one side as a characteristic feature.

The other yeast isolate was Candida albicans, which had a cream glistening and sometime waxy surface is smooth. The microscopic examination of Candida albicans was small oval with single budding sometime this yeast was give positive germ tube test.

\section{Study the effect of alternative oils on the Malassezia yeast growth}

Experiment showed that the best growth of Malassezia furfur was in the medium containing olive oil and sunflower oil. Either the medium with other treatment of castor oil appeared weak growing of Malassezia furfur, mixing oils as results of castor oil (Figure 1).

\section{Antifungal activity test}

Both aqueous and methanolic extracts showed effectiveness in inhibiting the growth of both yeasts. However, the effect of the extracts was higher with respect to the yeast $C$. albicans compared with the yeast $M$. furfur. The diameters of the inhibitory zone were $20 \mathrm{~mm}$ and $25 \mathrm{~mm}$ respectively for the aqueous and methanolic extracts. C. albicans (45) $\mathrm{mm}$ for aqueous extract and (3) $\mathrm{mm}$ for methanolic extracts (Table 1 and Figure 2).

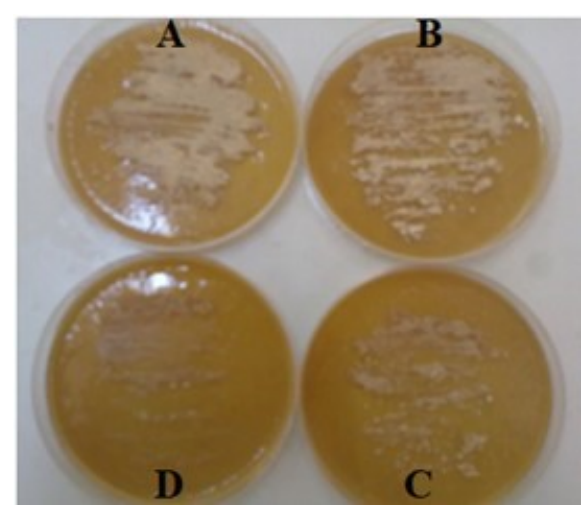

Figure 1 The growth of Malassezia furfur, on the medium containing different oils A-Olive oil B-Sunflower oil C-Castor oil D-Oil mixture

Table 1 The diameter of the inhibition zones of extracts toward yeasts

\begin{tabular}{|l|l|l|}
\hline \multicolumn{2}{|l|}{ Inhibition zone diameter(mm) } & Methanolic extract \\
\hline Yeast & Aqueous extract & 25 \\
\hline M. furfur & 20 & 30 \\
\hline C. albicans & 45 & \\
\hline
\end{tabular}

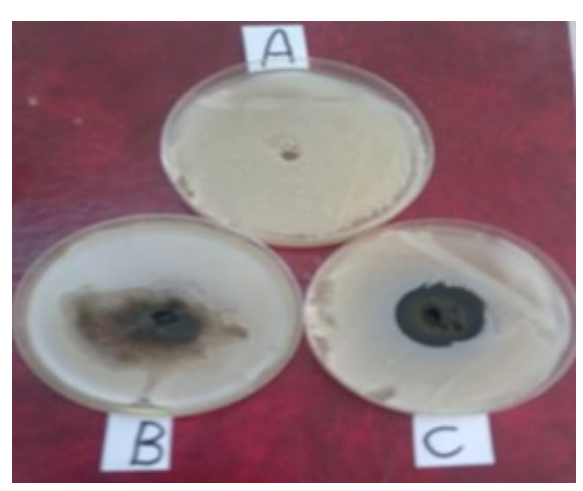

Figure 2 Indicate the diameters of the inhibition zone of $\mathrm{C}$. albicans in the effect of the extracts A-Control B-Aqueous extract C-Methanolic extract

\section{The MIC test for yeast}

The concentrations of 200 and $300 \mu \mathrm{g} / \mathrm{ml}$ showed a lack of growth for both extracts, MIC for C. albicans yeast $50 \mu \mathrm{g} / \mathrm{ml}$ in the aqueous extract and $75 \mu \mathrm{g} / \mathrm{ml}$ in the Methanolic extract.

MIC for $M$. furfur yeast in the treatment of the aqueous extract was $100 \mu \mathrm{g} / \mathrm{ml}$ and $75 \mu \mathrm{g} / \mathrm{ml}$ in methanolic extract obtained (Table 2). 
Table 2 MIC of extracts toward yeasts.

\begin{tabular}{|l|l|l|}
\hline \multicolumn{2}{|l|}{ MIC value $(\boldsymbol{\mu g} / \mathrm{ml})$} & Methanolic extracts \\
\hline yeast & Aqueous extracts & 75 \\
\hline M. furfur & 100 & 75 \\
\hline C. albicans & 50 & \\
\hline
\end{tabular}

\section{Antibacterial activity test}

Two positive and negative Gram bacteria were selected to determine the effect of Juglans regia extracts on them.
Methanolic extract showed a clear and almost fatal effect on most bacterial species (Table 3). Staphylococcus aureus showed the most sensitive germs, followed by Salmonella typhi.

Table 3 Results of the inhibitory effect and diameters of the inhibition zones in $(\mathrm{mm})$ for the aqueous and Methanolic extract against 6 bacterial isolates.

\begin{tabular}{|l|l|l|}
\hline \multirow{2}{*}{ Pathogenic Bacteria } & Diameters of $\mathbf{~ m m}$ inhibition zone & Water extract Mm/mg \\
\cline { 2 - 3 } & Alcoholic extract Mm/mg & 15.5 \\
\hline Staphylococcus aureus & 22.5 & 8 \\
\hline Pseudomonas aeruginosa & 7 & $\mathrm{R}$ \\
\hline Vibrio parahaemolyticus & 12.5 & 10 \\
\hline Salmonella typhi & 20 & 10 \\
\hline Proteus mirabilis & 11 & 10.5 \\
\hline Escherichia coli & 17.5 & \\
\hline Where R means resistance & & 10 \\
\hline
\end{tabular}

\section{The MIC for pathogenic bacteria}

Concentrations showed 50 micrograms/ml growth loss for all bacterial pathogens in both extracts. MIC for Vibrio parahaemolyticus and Pseudomonas aeruginosa $500 \mu \mathrm{g} / \mathrm{ml}$ in the water extract were $250 \mu \mathrm{g} / \mathrm{ml}$ in the alcohol extract.
MIC for Staphylococcus aureus showed a concentration of $50 \mu \mathrm{g} / \mathrm{ml}$ growth in the treatment of aqueous and methanolic extract and Table 4 shows this.

Table 4 The MIC of the pathogenic bacteria under study towards aqueous and alcohol extract.

\begin{tabular}{|c|c|c|c|c|c|c|c|c|}
\hline \multirow[b]{2}{*}{ Bacteria } & \multicolumn{2}{|c|}{500} & \multicolumn{2}{|c|}{250} & \multicolumn{2}{|c|}{100} & \multicolumn{2}{|c|}{50} \\
\hline & C & $\mathbf{w}$ & C & w & C & $\mathbf{w}$ & C & w \\
\hline Staphylococcus aureus & + & + & + & + & + & + & - & - \\
\hline Pseudomonas aeruginosa & + & - & - & - & - & - & - & - \\
\hline Escherichia coli & + & + & + & + & + & - & - & - \\
\hline Vibrio parahaemolyticus & + & - & - & - & - & - & - & - \\
\hline Salmonella typhi & + & + & + & - & - & - & - & - \\
\hline Proteus mirabilis & + & + & + & - & - & - & - & - \\
\hline
\end{tabular}

\section{Discussion}

The experiment demonstrated that olive oil and sunflower oil were comparable in their effectiveness to support the growth of $M$. furfur compared to castor oil [8] because it is high in density and complex structure which is difficult to digest into simple fatty acids by Lipase enzyme and contains a protein called Resin inhibits protein building in the cell.
The extract of Juglans regia was tested against $M$. furfur as tested for yeast $C$. albicans, and extract is used as a cosmetic to beautify the lips and whiten teeth in the mouth [13].

The use of plant extracts is still common due to the resistance of many types of yeast to antifungal agents. The extract of Artemisia abrotanum has been successfully used to inhibit the growth of yeast M. furfur and C. albicans [22]. 
Essential oils derived from orange and lemon has been found to be effective against the fungus $M$. Furfur, which causes varicose veins [23].

Juglans regia is used as an extract in the inhibition of the growth of many skin fungi and with high efficiency such as Epidermophyton flocosum and Trichophyton mentagrophytes and C. albicans. Al-Khawaja [13] noted that the use of Juglans regia plant in the mouth to clean the teeth and adornment increases the acidic function of the $\mathrm{PH}$ saliva, which leads to an antimicrobial action. The experiment proved superior to the aqueous than methanolic extract in the antimicrobial activity experiment on $C$. albicans and has a higher MIC, this is due to the ability of water to pull many compounds and active ingredients (alkaloids, tannins and amino acids) from their plant source [24]. While the result was reflected in the yeast of $M$. furfur in the effectiveness of antifungal activity and MIC, the methanolic extract was more effective in inhibition of the growth this is because to the fact that mehanol is able to extract flavonoids that may affect this yeast [25]. This is agreement with Qadan [26] found that phenolic compounds such as flavonoids have anti-fungal effects. Buttery noted that Juglans regia is containing terpenes and hydrocarbons Esters that have antifungal and antioxidants action such as phenolic compounds.

It is recognized that antibacterial resistance to antibiotics has been rising to dangerous levels around the world. Antibiotic resistance leads to prolonged hospital stay, high medical costs and increased mortality. New resistance mechanisms are emerging and spreading globally and threaten our ability to treat common infectious diseases [27-33].

\section{Conclusion}

Antibiotic resistance increases and spreads in cases where the over-the-counter purchase of antibiotics is considered for human or animal use. All these things called for rethinking the return to natural resources.

The results of the test of the efficacy of aqueous and methanolic extracts of Juglans regia as an anti-bacterial agent showed that gram-negative bacteria and gram-positive bacteria were affected by the both extracts used.

Juglans regia methanolic extract showed zone of inhibition against all tested bacterial strains, while the aqueous extract was active with relatively smaller inhibition zones, which is consistent. S. aureus and Salmonella typhi showed that they were the most sensitive species for the effect of methanolic extracts for the extract of water of the Juglans regia, bacteria $S$. aureus showed high sensitivity while Salmonella appeared less sensitive.

The results showed that bacteria Vibrio parahaemolyticus were sensitive to the alcohol extract, while the aqueous dermis showed no efficacy against them.

\section{Financial Support and Sponsorship}

Nil.
Conflicts of Interest

There are no conflicts of interest.

\section{References}

1. Ahmad S, Wahid MA (1973) Fungistatic action of Jumglans I3: 436-438.

2. AL-Khawajah AM (1997) Studies on the antimicrobial activity of Juglans regia. The Amer of chires. Medic (AJCM) 25: 170-180.

3. Alkhawajah A (2012) Studies on the Antimicrobial Activity of Juglans regia. The American Journal of Chinese Medicine 25.

4. Bansode DS, Chavan MD (2013) Evaluation of antimicrobial activity and phytochemical analysis of papaya and pineapple fruit juices against selected enteric pathogens. International Journal of Pharma and Bio Sciences 4: B1176-B1184.

5. Brodin K, Alahyar H, Heduer T, Faergemanr J (2007) Invitro Activity of Artemiisia abrotanum extract aginst malassezei spp. Candida albicans and staph. aureus. aceta Dermat. venergeologica, 87: 540-542.

6. Buttery RG, Fiat R, Mon TR, Anclling $C L$ (1986) Identification germacrene Din walnut and fig leat volatiles. TA food Chem 34: 820-822

7. Chopra RN, Copra IC, Handa KL, Kapur LD (1958) Indigenons drugsof India, 2nd ed. VN Dhur tsors, private Ltd. Calcutta.

8. Cutler JE (1991) Putative virulence factor of candida albicans. Anhu revmicro boil 45: 187-218.

9. Dismukes W, Pappas P, Sobel J (2003) Clinical Mycology Oxford University Press, 504.

10. Dorlons WA (1951) Quotel in Americn illust voted medical dictionary, 22nd ed. Saunders and Co. Philadelphia.

11. Grim show J (1976) Despsides, hydrolysable tannins, lignans, lignin and Humic acid. coffeye 11 Pewt D. elsever scientific puplishemy co. Amsterdam, Netherlands.

12. Gueho Midgley G, Guollot J (1996) The genus Malassezia with description of four new species Antoine van Leeuwenhoek 96: 337-557.

13. Gueho E, Boekhout T, Ashbee guillot J, vanbelkun A, faergemann $J$ (1998) The role of Malassezia species in the ecology of human skin as pathogen. Med Mycol 36: 220-229.

14. Gupta PG, Birdi TJ (2017) Development of botanicals to combat antibiotic resistance. J Ayurveda Integr Med 8: 266-275.

15. Handa SS, Khanja SPS, Longo G, Rakesh DD (2008) Extraction Technologies for medicinal and Aromatic plants, International Centre for Science and High Technology, Trieste 21-25.

16. Harborn JB (1984) Phytochemical Methods chpman and Hall, London, UK.

17. Ingham E, Cunningham A (1993) Malasszia furfur. J Med and Vet Mycol. 31: 265-288.

18. Leberer E, Zigelbauer K, Schmidt A (1997) Virulance and hyphat formation of condida albicans vequire the stezop-like protion kinase caclou p. current biology 7: 539-546.

19. Lo HJ, Kohler JDI, Domenico BL, Domenico B, Loebenberge (1990) Non filamentous C. albicons mutants are avivule cell 90: 939-949.

20. Lucia KH, Cecilia MA, Pedro HF (2003) Antimicrodial Activity of huptis ollaliforia towaral dermato phytes. Men Inst of Fwado Cruze Riode Janerio 98: 963-965. 
21. Midgley G, Gueho E, Guillot J (1997) Diseases caused by Malassezia spp. in: Medical Mycolog. (eds.) Hay RJ and Ajello L Arnold Publ, London 4: 201-211.

22. Qadan FA, Thewaini DA, Ali RA, Matalka KZ (2005) The Antimicrobial activity of Psidium Gnajawa and Juglans regia leaf extract to ocnedeveloping organisms amrec. Jour Chin Med (AJCM) 33: 197-205.

23. Ran Y, Yoshiike T, Ogawa $H$ (1993) Lipase of Malassezia same pro per ties and their relationship to cell growth. J Med veta myccel 31: 77-85.

24. Rossiter SE, Fletcher MH, Wuest WM (2012) Natural Products as Platforms to Overcome Antibiotic Resistance. Chem Rev 117: 12415-12474.

25. Ryley JF, Ryley MG (1995) Candida albicans - do mycelia matter? Jmed Vetmycol 28: 225-239.

26. Salamat F, Keivani S, Amin G (2006) Evolution of Juglans regia. pericrp on antifnng susceptibility with both dilution method. Med Scen Jour of Islamic Azad vniv. 16: 201-205.

27. Sharafati Chaleshtori R, Sharafati-Chaleshtori F, Rafieian-Kopaei M (2011) "Biological characterization of Iranian walnut (Juglans regia) leaves," Turkish Journal of Biology 35: 635-639.
28. Sharma R, Sharma G, Sharma M (2012) Anti-Malassezia furfur activity of essential oil against causal agent of pityrias versicolor disease African Jaur. Of Pharmacy and pharmacology vol 6: 979-983.

29. Spooner DF, Sykes G (1972) Laboratory assessment of antibacterial activity. In: nnethodsin microbiology, Norris JR, Ribbors DW (eds) 7: 211-278.

30. Sytykiewiez H, Chrzanowski G, Czerniewic P, Leszczyns B (2015) Antifungal activity of Juglans regia (L.) leaf extracts against Candida albicans isolates. Pol J Environ Stud 24: 1339-1348.

31. Tiwari R, Tiwari G (2011) Use of antibiotics: from preceding to contemporary. Scholars Res J 1: 59-68.

32. Yarrow D, Ahearn D (1984) Malassezia Bailion in the yeasts. A taxonomic study. (3rdedn) kreqer-van Rij. NJW Amsterdam Elsevier science publishers Bv 882-885.

33. Zakavi F, Hagh L, Daraeighadikolaei A, Sheikh A, Daraeighadikolaei A, et al. (2013) Antibacterial Effect of Juglans Regia Bark against Oral Pathologic Bacteria. International Journal of Dentistry P: 5. 